\title{
PODĄŻAJ ZA SZCZUREM. OD NEKROPOLITYKI DO TEORII MIĘDZYGATUNKOWEJ KOHABITACJI
}

\author{
GABRIELA JARZĘBOWSKA
}

\begin{abstract}
Abstrakt: Artykuł jest rozwinięciem koncepcji posthumanistycznego, ludzko-nie-ludzkiego kolektywu, skoncentrowanym na konfliktowej relacji między ludźmi a szczurami kanałowymi. Przyglądam się brakowi empatii w programach eksterminacji tych zwierząt, zwracając uwagę na nekropolityczną narracje wojny i kolonizacji dominująca w dyskursie okołoderatyzacyjnym. Próbuję odpowiedzieć na pytanie, jak powinna być zorganizowana międzygatunkowa wspólnota, żeby chroniąc interesy ludzi, spełniała zarazem podstawowe wymogi dobrostanu zwierząt. Analizuje główne przyczyny, dla których pomysły ograniczenia cierpienia zwierząt w programach deratyzacyjnych nie funkcjonują w debacie publicznej. Stawiam tezę, że dla stworzenia międzygatunkowego kolektywu złożonego z populacji pozostających w konflikcie, konieczne jest zaangażowanie aktywistów prozwierzęcych, transparentność praktyk oraz upowszechnienie alternatywnych kodów kulturowych określających wizerunek szczura.
\end{abstract}

Słowa kluczowe: szczur, posthumanizm, prawa zwierząt, nekropolityka, wspólnota 


\section{Wprowadzenie}

Celem niniejszego artykułu jest przedstawienie modelu teoretycznego, który mógłby stanowić punkt wyjścia dla teorii kohabitacji wolno żyjących szczurów i ludzi. W praktyce oznaczałoby to wypracowanie takich form kontroli populacji tych zwierząt, w których zminimalizowany byłby negatywny wpływ na dobrostan osobniczy ${ }^{1}$. Artykuł należy rozpatrywać w kontekście dyskusji na temat teorii wspólnoty poszerzonej obejmującej ludzko-nie-ludzki kolektyw aktorów (Kowalczyk, 2010; Radomska 2010). Konieczne jest przemyślenie, jak w praktyce miałaby wyglądać taka poszerzona, posthumanistyczna wspólnota i jakie polityczne zasady miałyby nią kierować. Do badania możliwości jej stworzenia wybrałam przykład relacji ludzi i szczurów kanałowych, po pierwsze dlatego, że obejmuje on aktorów posiadających udowodnioną naukowo podatność na cierpienie ${ }^{2}$ (co pozwala włączyć do naszych rozważań ugruntowaną w doznaniach refleksję etyczna), po drugie zaś dotyczy relacji o problematycznym charakterze, bazującej na konkurencji, przemocy i oporze, co utrudniając osiągnięcie stanu harmonijnej koegzystencji, pozwala zarazem uniknąć naiwności w tworzeniu nadmiernie idealistycznych rozwiązań.

Teoria „wspólnoty poszerzonej” wyrasta na gruncie posthumanizmu, stanowiącego ważny punkt odniesienia dla niniejszych rozważań. Artykuł nie przedstawia kompleksowej dyskusji z jego założeniami. Dla porządku należy jednak odnotować, że ten cieszący się w ostatnich dekadach dużą popularnością nurt w humanistyce doczekał się swoich krytyczek i krytyków (por. Herbrechter 2013, Weisberg 2014), wypunktowujących jego kłopotliwe, a czasem wręcz niebezpieczne aspekty, takie jak fetyszyzacja rozbicia granic międzygatunkowych, hybrydyczności i technonauki, pełne samozadowolenia teoretyzowanie będące formą jałowego ćwiczenia intelektualnego zamiast dogłębnej, usytuowanej w konkretnych praktykach analizy oraz, wbrew postulatom, brak refleksji etycznej dotyczącej naszej relacji z nie-ludzkimi zwierzętami (Weisberg 2014). Zipporah Weisberg zwraca też uwage na niebezpieczeństwa płynące z zastosowania idei sfetyszyzowanej hybrydyczności w praktyce, takie jak na przykład ksenotransplantologia, i wprost nazywa posthumanizm

1 Artykuł towarzyszy doktoratowi przygotowywanemu na Wydziale Artes Liberales Uniwersytetu Warszawskiego, w którym badam branżę deratyzacyjną w Polsce, m.in. prowadząc wywiady i obserwację terenową. Celem dysertacji jest zbadanie możliwości wypracowania bardziej humanitarnych form kontroli tych zwierząt.

2 Obecnie panuje naukowy konsensus co do tego, że kręgowce odczuwają ból (Bateson 1991). Badania z lat siedemdziesiątych i osiemdziesiątych potwierdziły, że gryzonie posiadają receptory bólowe i opioidowe, a także podobną do ludzkiej strukturę mózgu. Badanie za pomocą rezonansu magnetycznego pokazuje, że podczas doświadczenia bólu u tych zwierząt aktywują się te same obszaru mózgu co u człowieka w podobnej sytuacji (Smit 1999, 317). Szczury posiadaja ponadto wysokie zdolności kognitywne. Doświadczenia z ich udziałem dowiodły, że maja poczucie czasu, kompetencje przestrzenne (znajdowanie drogi w labiryncie, odnajdowanie ukrytych przedmiotów) oraz potrafią rozwiązywać proste zadania logiczne (Davis 1996). Posiadają także skomplikowany system społeczny (Macdonald 1999, 54-55) oraz potrafią odczuwać emocje (Makowska i Weary 2013). 
„teorią pornograficzną", opartą na szukaniu tanich intelektualnych podniet. Mając na względzie tę krytykę, warto jednak podjąć próbę użycia posthumanistycznej wrażliwości dla wypracowania rozwiązań politycznych na gruncie relacji międzygatunkowych. Aby osiągnać ten cel, należy zaznaczyć, że płaska ontologia nie musi (i nie powinna) pociagać za sobą płaskiej etyki i że przełamanie „ontologicznej higieny” (Graham 2002) nie oznacza od razu całkowitego pozbycia się ucieleśnionego, doświadczającego cierpienia jednostkowego podmiotu.

Współczesne praktyki eksterminacji miejskich szczurów, będące integralnym, choć zazwyczaj silnie stabuizowanym aspektem polityki zarządzania przyrodą w mieście, nie funkcjonują whistorycznej i aksjologicznej próżni. Podobnie jak wszelkie inne praktyki społeczne są konsekwencja i rozwinięciem procesów definiowania problemów, formowania znaczeń i tworzenia polityk bazujących na kumulacji wielopokoleniowej wiedzy, ale także przesądów i założeń uznanych za oczywiste, wynikających z zakorzenienia owych praktyk w określonym kontekście aksjologicznym. Poddanie pod dyskusję jednej z najtrudniejszych relacji człowieka z nie-ludzkimi gatunkami, jaką jest relacja człowiek-szczur, wydaje się dobrą okazją do wypracowania rozwiązań wyłamujących się z antropocentrycznej perspektywy, zarazem jednak silnie usytuowanych w określonym kontekście społeczno-politycznym i pozbawionych filozoficznego dogmatyzmu.

Obecność szczurów w przestrzeniach zurbanizowanych łączy się z wieloma problemami natury sanitarnej, ekonomicznej oraz psychologicznej, sprawiającymi, że samo postawienie kwestii w taki sposób, w jaki zarysowałam ją na wstępie, może powodować jej niezrozumienie, a nawet odrzucenie. Ponadto konieczne jest znalezienie satysfakcjonującego modelu filozoficznego, który mógłby stanowić punkt wyjścia dla wypracowania alternatywnych rozwiązań. Może to być kłopotliwe o tyle, że większość koncepcji włączających zwierzęta do swojej refleksji etycznej opiera się na monadycznej, jednostkowej teorii praw/interesów, które, jak zobaczymy dalej, wymykają się specyfice relacji między szczurzymi a ludzkimi zbiorowościami. Dlatego kluczowe dla naszej refleksji będzie jej silne ugruntowanie w materialnych praktykach. Wychodzę bowiem z założenia, że chociaż dyskusja dotycząca włączania nie-ludzkich zwierząt do moralnej wspólnoty toczy się od kilku dekad, zbyt rzadko wychodzi poza bazująca na spekulacji refleksję filozoficzna, mająca niewielki wpływ na ucieleśnione doświadczenie jednostek. Niebezpieczne jest także konceptualizowanie relacji ludzi z innymi gatunkami poprzez włączanie ich do szerokiej kategorii „natury”, która może nie uwzględniać specyfiki skomplikowanych stosunków międzygatunkowych. Widać to zwłaszcza na gruncie urban studies. Narracja dominująca 
w publikacjach postulujących stworzenie nieantropocentrycznego, posthumanistycznego i wielogatunkowego miasta rzadko pozwala dostrzec problematyczne aspekty relacji ludzi z innymi zwierzętami, a jeśli nawet, zazwyczaj są one omawiane na przykładach mniej kontrowersyjnych gatunków, takich jak wolno żyjące koty, szopy czy dziki, łatwiej wpisujące się w pojęcie „natury”.

Dobrym przykładem takiej narracji jest ta zawarta w skądinąd ważnym i potrzebnym artykule Jennifer Wolch (Wolch 1998), w którym postulat ponownego „zazwierzęcenia” miast autorka wsparła argumentem, że obecność zwierząt w mieście jest korzystna dla człowieka, dostarcza mu bowiem wiedzy na temat funkcjonowania przyrody, przydatnej m.in. w zarządzaniu krajobrazem i w bioinżynierii. Autorka wspomina wprawdzie, że niektóre gatunki, takie jak szczury i karaluchy, doskonale przystosowały się do życia w mieście, ale nie rozwija tego wątku i nie konkluduje, jakie konsekwencje dla ludzi i samych szczurów może mieć niekontrolowany rozrost ich populacji. Podobna narracja pojawia się w tekście Joyce Hwang (Hwang 2013), która budując pozytywną narrację wokół relacji między ludźmi a miejskimi „szkodnikami”, pomija problem szczurów; proponowana przez nią strategia przemyślenia idei brudu i traktowania odpadów jako „wartościowego zasobu” wspiera rozwiązania, które generuja rozwój szczurzych populacji, a tym samym, pośrednio, rozmiar prowadzonej później eksterminacji3 ${ }^{3}$.

Zanim przejdziemy do teoretycznej analizy zjawiska, spróbujmy je usytuować w realnych praktykach, przyglądając się pobieżnie dominującym metodom eksterminacji szczurów oraz towarzyszącemu jej dyskursowi. Warto zaznaczyć, że w przeciwieństwie do innych form wykorzystywania zwierząt, takich jak chów przemysłowy czy doświadczenia laboratoryjne, praktyki deratyzacyjne nie są objęte żadnymi prawnymi ograniczeniami, które mogłyby, przynajmniej w założeniach, minimalizować cierpienie zwierząt. Jedynymi kryteriami, które bierze się pod uwage przy planowaniu i implementacji owych praktyk, są efektywność, szybkość działania, koszt i (rzadziej) oddziaływanie na środowisko, ludzi oraz gatunki niedocelowe. Dodać trzeba, że obecność szczurów jest silnie powiązana ze społecznym statusem mieszkańców danej dzielnicy. Owa zależność między szczurami

\footnotetext{
${ }^{3}$ Por. też Annabelle Sabloff, która w swoich analizach relacji ludzko-zwierzęcych w mieście badała kliniki weterynaryjne, ogrody zoologiczne, organizacje prozwierzęce oraz wystawy zwierząt rasowych. Uderza tu nieobecność relacji innych niż udomowienie, co w konsekwencji prowadzi do (zbyt) optymistycznych wniosków (Sabloff 2001). Narracja Sabloff jest explicite zakorzeniona w teorii biofilii Edwarda O. Wilsona, podobnie jak książka Beatleya (Beatley 2011), gdzie zwierzęta włączone są w zbiorowe pojęcie „natury”. Poza jedną stroną, na której autor w większym stopniu skupia się na zwierzętach, słowo animals pojawia się w książce zaledwie 13 razy, głównie w takich zbitkach jak plants and animals lub animal species. Ptaki goszczą na łamach książki Beatleya niemal wyłącznie w takich kontekstach jak watching birds i migratory birds. Ssaki są tam jedynie morskie (marine mammals), ewentualnie prezentują swoje wdzięki w zdaniu „a number of small mammals to watch". Słowa cats, pigeons i rats w ogóle w książce nie występują. Nad biophilic city unosi się gęsta zasłona dymna, skrywająca niechciane aspekty ludzko-zwierzęcej koegzystencji. O niedostrzeganiu indywidualnych zwierząt w koncepcjach ekomiast - zob. też: Palmer 2003.
} 
a wykluczeniem społecznym jest skomplikowana. Na przykład w Nowym Jorku jedna z dzielnic najbardziej narażonych na obecność tych zwierząt jest Harlem - można to łączyć z faktem, że jego mieszkańców zazwyczaj nie stać na zatrudnienie zewnętrznych firm sprzątających i dbających o czystość dzielnicy, co jest podstawowym środkiem prewencyjnym przeciw rozrostowi populacji szczurów ${ }^{4}$. Bezrefleksyjne powiązanie szczura z biedą i patologiami społecznymi stało się jednak, co najmniej od połowy dwudziestego wieku, charakterystyczne dla powszechnego postrzegania tego gatunku. Ten aspekt, połączony z niskim statusem symbolicznym szczura, jego nocnym trybem życia i brakiem transparentności deratyzacyjnych praktyk (powodującym fizyczne i mentalne odcięcie mieszkańców od cierpienia zwierząt), a także z bazującymi na sensacji przekazami medialnymi i niewielkim zainteresowaniem ze strony organizacji prozwierzęcych, mógł mieć wpływ na stworzenie sytuacji, w której okrucieństwo działań deratyzacyjnych nie funkcjonuje w percepcji społecznej ani w powszechnym dyskursie.

Obecnie najpowszechniej stosowanymi na świecie środkami eksterminacji szczurów są antykoagulanty, a więc środki zaburzające proces krzepnięcia krwi, co powoduje liczne krwawienia wewnętrzne. Wszystkie ważniejsze badania naukowe określaja je jako posiadające bardzo negatywny wpływ na dobrostan zwierząt (Mason i Littin 2003, Broom 1999, Sharp i Saunders 2011, Littin i in. 2014). Mason i Littin podkreślają, że o ile samo krwawienie nie powoduje silnego bólu, to gromadzenie się krwi w komorach ciała i organach (płuca, nerki, oczy) już tak. Jednak głównym czynnikiem stanowiącym o negatywnym wpływie antykoagulantów na dobrostan jest długość występowania objawów klinicznych, trwających zazwyczaj od kilku godzin do trzech dni, choć niektóre badania dowodziły, że moga one trwać nawet pięciu dni. Różnice w czasie umierania mogą wiązać się z różnymi czynnikami, jako najważniejszy z nich autorki wymieniaja stężenie trucizny - im większe, tym objawy kliniczne trwają krócej (Mason i Littin 2003). Warto w tym miejscu nadmienić, że zgodnie z rozporządzeniem unijnym nr 2016/1179 stężenie antykoagulantów dostępnych do powszechnego użytku ma ulec zmniejszeniu od 2018 roku. Można domniemywać, że w świetle przytoczonych powyżej informacji nie pozostanie to bez wpływu na dobrostan zwierząt.

Popularne są także pułapki klejowe - kontrowersyjne $z$ uwagi na swoje okrucieństwo. Z tego powodu zostały zakazane w kilku krajach, m.in. w Nowej Zelandii, w Polce jednak można je kupić bez ograniczeń. Teoretycznie zwierzęta złapane w pułapkę klejową powinny być „humanitarnie uśmiercone”. Mason i Littin konkludują jednak,

\footnotetext{
4 Informacja otrzymana podczas obserwacji uczestniczącej na szkoleniu dla pracowników deratyzacji w Nowym Jorku (Rat Academy), organizowanym przez New York City Department of Health and Mental Hygiene, 16.11.2016. Por. też: Feng i Himsworth 2014, które podkreślają, że biedne dzielnice, „oferujące” dostęp do przestrzeni i jedzenia (śmieci), są częściej narażone na rozrost szczurzych populacji. Więcej o społeczno-rasowych aspektach kontroli szczurów w USA: Biehler 2013, 111-176.
} 
że weryfikacja owej „humanitarności” jest niezwykle trudna, zwłaszcza w krajach, w których pułapki tego typu są dostępne w powszechnej sprzedaży. W badaniach, które przywołują autorki, pojawiaja się przekazy o szczurach odgryzających własne kończyny, aby uwolnić się z pułapki, czy duszących się godzinami w kleju zatykającym pysk i nozdrza (Mason i Littin 2003). Można by sądzić, że takie sytuacje są jedynie sporadycznymi „wypadkami przy pracy”. Wywiady z osobami zajmującymi się deratyzacja pozwalaja jednak podejrzewać, że opisane sytuacje są raczej reguła niż wyjątkiem. Kiedy podczas rozmowy z Robertem Corriganem, jednym z najważniejszych na świecie ekspertów od deratyzacji, zadałam pytanie, w jaki sposób uśmiercane są szczury złapane w pułapki klejowe, odparł, że zazwyczaj zwierzęta sąuż martwe, gdy pracownicy zbieraja pułapki. Dodał zarazem, że dzieją się tam rzeczy „straszne”.

Rozpoznanie okrucieństwa stosowanych praktyk nie pociaga za sobą zazwyczaj propozycji ich zaprzestania. Odpowiedź na pytanie, dlaczego tak się dzieje, jest skomplikowana. Wśród możliwych przyczyn Mason i Littin wskazują na dyskurs efektywności, zgodnie z którym szybkie pozbycie się problemu stanowi główne i zazwyczaj jedyne kryterium doboru metody kontroli, brak przejrzystości w procedurach i praktykach, brak dokładnych danych dotyczących oszacowania dobrostanu, tryb życia szczurów sprawiajacy, że ich śmierć jest niezauważalna - a także brak presji społecznej i zainteresowania mediów. Warto podkreślić, że zwierzęta zabijane na pokarm czy w laboratoriach nigdy nie moga cierpieć tak długo, jak te będące ofiarami praktyk deratyzacyjnych. Warunki ich wykorzystywania i zabijania reguluja bowiem odpowiednie procedury, zgodnie z którymi śmierć powinna być, przynajmniej w teorii, możliwie szybka. Przykładowo jeśli zwierzę domowe lub laboratoryjne podtruje się antykoagulantem, przeprowadza się na nim eutanazję, aby skrócić jego cierpienie. Okrucieństwo metod stosowanych w deratyzacji jest więc znane specjalistom, ale ignorowane.

W przypadku szczurów w grę może wchodzić jeszcze jeden czynnik. Zarówno w dyskursie naukowym, jak i medialnym relacje między szczurem a człowiekiem często definiowane sa przez metafory wojny, podboju i inwazji. Narracja definiująca ten gatunek jako odwiecznego wroga Homo sapiens, konsekwentnie siejącego zniszczenie, podjęta przez Zinssera (Zinsser 1935), a następnie powielana przez kolejnych autorów, dyskurs branżowy oraz teksty kultury ${ }^{5}$ - przez co stała się niemalże kodem kulturowym - ma pewne podstawy w ekologii naszych gatunków, będących od stuleci konkurentami w walce o zasoby. Owa wojenna retoryka nosi w sobie jednak silny potencjał performatywny, definiując

\footnotetext{
${ }^{5}$ por. np. Hendrickson 1983. Warto przyjrzeć się wizerunkowi szczura powielanemu przez kulturę wizualną - ulotkom reklamującym rodentycydy, stronom internetowym firm DDD czy filmom (np. horrory Willard, 1971, reż. D. Mann czy The Rats, 2002, reż. J. Lafia lub dokument Rats, 2016, reż. M. Spurlock) - żeby zauważyć, jak wszechobecny jest topos szczurów jako śmiertelnie niebezpiecznych najeźdźców, dokonujących inwazji na miejski/ludzki habitat.
} 
i usprawiedliwiając nasze bezlitosne metody eksterminacji szczurów. Warto zwrócić uwagę zwłaszcza na metafory inwazji i kolonizacji, za sprawą których nielubiane zwierzęta - w tym wypadku szczury - sa postrzegane jako dokonujące aktu agresji na własność człowieka, jego zdrowie, a nawet życie ${ }^{6}$. Odrębnym, bo nie dotyczącym wyłącznie szczurów, ale ważnym dla niniejszych rozważań pojęciem jest stworzone w latach czterdziestych przez Charlesa Eltona pojęcie inwazji ekologicznej, zakładające walkę z gatunkami obcymi, nierodzimymi, stanowiącymi poważne zagrożenie dla rodzimych ekosystemów. Termin „gatunki inwazyjne” ujawnia nie tylko nasze przekonanie o tym, czym powinna być przyroda, jakie gatunki są w niej mile widziane, a jakie wymagaja eksterminacji, ale stanowi także nieświadomie replikowana przez naukowców narrację używaną wcześniej do opisywania niechcianych grup ludzi (Nagy i Johnson 2013)7. Jak jednak dowodzi Richard Twine, pojęcie kolonizacji w odniesieniu do relacji ludzko-zwierzęcych powinno być rozumiane nie jako sytuacja dana raz na zawsze, ale jako ciagły, dynamiczny proces negocjacji, transformacji i oporu, wymykający się binarnej opozycji kat-ofiara (Twine 2010, 48).

W definiowaniu dynamiki relacji między szczurem a człowiekiem przydatna może być wypracowana w obszarze studiów postkolonialnych koncepcja nekropolityki (Mbembe 2003). Przypomnijmy, że Achille Mbembe opisuje ja jako kontrolę nad śmiertelnościa, w której życie staje się manifestacja potęgi, a wojna z towarzyszącym jej prawem do zabijania - metoda egzekwowania władzy suwerennej. W wyobrażeniu imperialnym kolonie zamieszkane były przez „dzikich”, których życie stanowiło formę życia zwierzęcego. Owa symboliczna degradacja, będąca efektem utożsamienia ludów rdzennych ze zwierzętami, otwierała drzwi dla indyferentyzmu moralnego, zgodnie z którym niebiali mieszkańcy kolonii nie byli podmiotami moralnymi, a ich wykorzystywanie i eksterminacja nie nosiły znamion czynu niepożądanego. Jako nieposiadające regularnej armii, ludy rdzenne były uznawane za niezdolne do zawarcia pokoju, zatem wojna na podbitych przez kolonialistów terenach stała się stanem permanentnej wrogości, utrzymywanym na zasadzie „prawa wyjątku” (state of exception), w którym normy moralne i standardy legislacyjne zostaja zawieszone, a przemoc może być stosowana w imię „cywilizacji”. Warto zwrócić uwagę na podkreślana przez autora percepcję Innego jako śmiertelnego zagrożenia dla życia podmiotu, w związku z którą biofizyczna eliminacja wroga wyraźnie wzmacnia bezpieczeństwo i żywotność drugiej strony. Użycie pojęcia nekropolityki do opisania relacji ludzko-zwierzęcych zaproponowała (na gruncie literaturoznawstwa) Sarah Groeneveld (Groeneveld 2014). Jednak jej propozycja

${ }^{6}$ O logice kolonizacji w odniesieniu do „problematycznych” zwierząt zob. np. Cronon 2013, 7; Jerolmack 2014.

7 Powołując się na Davisa, Brendon Larson twierdzi, że pojęcie ekologii inwazji było konsekwencja wojennych doświadczeń Eltona, zwłaszcza tych związanych z próbą inwazji wojsk nazistowskich na Wielką Brytanię, co potwierdzałoby militarystyczny trop naszych rozważań (Larson 2013, 139). Polemikę z założeniami ekologii inwazji rozwija także Fred Pearce (Pearce 2015). 
dosyć luźno nawiązuje do koncepcji Mbembego, koncentrując się na ogólnym zjawisku polityki zwierzęcej masakry jako wymykającej się narracjom biopolitycznym. Warto jednak przyjrzeć się bliżej zależnościom między pojęciem nekropolityki a relacjami międzygatunkowymi, wydaje się bowiem, że akurat w przypadku szczurów (i, w mniejszym stopniu, także innych zwierząt określanych mianem „szkodników” i „gatunków inwazyjnych") może ono trafnie opisywać dynamikę tworzenia strategii eliminacji zwierząt. Permanentny stan wojny człowieka ze szczurem, w którym wszelkie prawa (tu: zawarty w ustawie o ochronie zwierząt zakaz powodowania niepotrzebnego cierpienia) zostaja zawieszone z uwagi na stan wyższej konieczności, motywuje paradygmat braku alternatywy wobec okrucieństwa. Dominuje przy tym narracja definiująca szczura jako Innego, stanowiącego śmiertelne zagrożenie dla ludzkiej egzystencji i własności (te dwie zagrożone wartości są przy tym zazwyczaj wymieniane jednym tchem, co, zwłaszcza w rozwiniętych krajach Północy, nienarażonych na spowodowany przez gryzonie głód, wydaje się symptomatyczne dla ideologicznego ukształtowania mentalności społeczeństw późnego kapitalizmu).

Mark L. Winston w książce pod znamiennym tytułem Nature wars. People vs pests zwraca uwagę na paradoksalność sytuacji, w której odrębny termin („szkodnik”) używany jest na opisanie relacji ekosystemowej opartej na konkurencji o zasoby - w świecie pozaludzkim uważanej za całkowicie „naturalną” i poprawna - tylko dlatego, że dotyczy relacji, w której jedną stroną jest gatunek ludzki (Winston 1997, 1). Zdaniem tego badacza, choć konkurencja człowieka o zasoby z innymi gatunkami istniała od czasów prehistorycznych, zjawisko „szkodnika” we współczesnej formie wyłoniło się razem z tworzeniem dużych skupisk ludzkich, a wraz z nimi - nadwyżek żywności. Proces ten zintensyfikował się wraz z zaistnieniem kapitalistycznych monokultur zaburzających relacje ekosystemowe, a także kolonializmu sprawiającego, że szczury zostały rozprzestrzenione po całym świecie (Winston 1997, 6-7), zyskując status "gatunku inwazyjnego”, co stanowi kolejny punkt styczny między ich feralnym statusem a zjawiskiem kolonizacji. Także pojęcie tzw. „szkodników sanitarnych” wydaje się przynajmniej w części pokłosiem ludzkich decyzji. Tezę o chorobach odzwierzęcych jako konsekwencji procesu udomowienia zwierząt przywołuje m.in. Jared Diamond (Diamond 2010, 167-186). Antropogeniczna geneza zjawiska, w ramach którego zwierzęta wykorzystuja stworzone przez człowieka warunki, a następnie są z tego powodu karane, jest istotna dla naszych rozważań. Young zwraca uwage na mechanizm definiowania szkody w odniesieniu do zwierząt określanych mianem szkodników. Podkreśla, że sposób definiowania jednostek odpowiedzialnych za szkodę, na przykład określanie chorych zwierząt mianem „wektorów choroby”, jest wyraźnie nacechowany wartościująco (value laden). Odwołując się do koncepcji Garfinkela zawartej w książce Forms of Explanation, zauważa, że w procesie definiowania szkody mamy tendencję do koncentrowania się na przyczynach, 
które możemy kontrolować, gdy zaś jest to niemożliwe, definiujemy jako kluczowy ten element, który minimalizuje naszą odpowiedzialność za zaistniała sytuację. Dlatego, zdaniem autora, winą za epidemię obciążamy jej inne, nie-ludzkie ofiary, od których możemy się zarazić, nie przykładając wagi do czynników antropogenicznych. W ten sposób usprawiedliwiamy eksterminacje problematycznych gatunków (Young 2006).

Warto teraz rozważyć, czy którakolwiek z propozycji wypracowanych na gruncie etyki może okazać się przydatna w budowaniu alternatywnych form międzygatunkowej kohabitacji między szczurem a człowiekiem. Już pobieżny przegląd założeń stojących zarówno za teoriami deontologicznymi (przede wszystkim prawa zwierzą), jak i utylitarystycznymi (teoria Petera Singera) pozwala jednak zauważyć, że choć mogą one stanowić ważny punkt wyjścia dla zadania, które sobie postawiliśmy, posiadają także szereg ograniczeń, utrudniających ich praktyczne zastosowanie ${ }^{8}$.

Popularna doktryna Petera Singera bywała krytykowana z wielu stanowisk, między innymi z feministycznego, zgodnie z którym „niezależnie myślący, neoliberalny podmiot samodzielnie podejmujacy decyzje” (Żylińska 2013, 38) jest konstruktem nie biorącym pod uwage cielesnego usytuowania decyzji etycznych, zwłaszcza ich relacyjnego charakteru9 Warto zwrócić uwagę na jeszcze inne jej istotne ograniczenie w kontekście rozwiązywania problemów między populacjami szczurów i ludzi. Jest nim fakt, że planując i realizując praktyki deratyzacyjne, jesteśmy skazani na funkcjonowanie w paradygmacie skrajnej niepewności - zarówno jeśli chodzi o konsekwencje naszych działań, jak i same zagrożenia generowane przez szczury.

Aby uświadomić sobie skalę owej niepewności, należy sięgnąć do rozwijanych na gruncie socjologii koncepcji związanych z zarządzaniem ryzykiem. Autorzy zajmujący się tym problemem wyraźnie podkreślaja, że oceny ryzyka nie mają charakteru obiektywnego, gdy w grę wchodzi zagrożenie, fakty są bowiem nierozerwalnie związane z ramami aksjologicznymi, w których funkcjonuja. Koncepcja społecznego wzmocnienia ryzyka opracowana przez Kaspersonów zakłada, że percepcja określonego rodzaju ryzyka wynika z kulturowo wytworzonych, przyjętych heurystyk (Arnoldi 2011, 142). Na jego subiektywną ocenę może też wpływać „czynnik strachu”, a więc afektywnie ugruntowany element

\footnotetext{
${ }^{8}$ Główne stanowiska związane z teorią praw zwierząt omawia Dorota Probucka (Probucka 2013)

9 Pisząc o ograniczeniach bioetycznej refleksji autorów takich jak Singer, Finnis i Tooley, Żylińska zwraca też uwagę, że w ich optyce ,zarówno moralnym podmiotem sprawczym, jak i przedmiotem rozważań bioetycznych mogą być jedynie odrębne jednostki wyłuskane z sieci stosunków społecznych i uwarunkowań politycznych oraz z materialnych i dyskursywnych okoliczności składających się na ich powstanie”.
} 
„zakłócający” jego postrzeganie (Arnoldi 2011, 27). Jak zauważa Mary Douglas: „ryzyko to broń masowego przymusu” (Douglas 1982, 6), wykorzystywana do utrzymania porządku społecznego w taki sposób, że zaczyna przypominać tabu funkcjonujące w tradycyjnych kulturach jako metoda integracji społecznej.

Ma to duże znaczenie w kontekście ryzyka, jakie wiąże się z obecnością szczurów w sąsiedztwie człowieka. Uświadamia bowiem, że przeprowadzenie utylitarystycznej oceny zagrożenia dla człowieka, jeśli nie jest niemożliwe, to na pewno pozostaje niezwykle trudne. $\mathrm{Z}$ jednej strony mamy bowiem do czynienia $\mathrm{z}$ realnym - w znaczeniu: fizycznym, namacalnym - choć społecznie ignorowanym cierpieniem tysięcy zwierząt poddawanych bolesnym praktykom deratyzacyjnym. Z drugiej strony - z zagrożeniami dla zdrowia, a może i życia przedstawicieli społeczności naszego gatunku. Owe zagrożenia są wyłącznie potencjalne, jednak w przypadku ich wystapienia mogłyby przynieść katastrofalne skutki. Stoimy więc przed dylematem: czy występujące tu i teraz, udowodnione naukowo cierpienie wielu nie-ludzkich osobników może lub powinno okazać się ważniejsze niż potencjalne mało prawdopodobne, ale niewykluczone - cierpienie jednej, dziesięciu, tysiąca osób należących do naszego gatunku? Problemem jest to, że nie mamy (nie możemy mieć?) wystarczającej wiedzy na temat prawdopodobieństwa wystąpienia epidemii na szeroką skalę. Dowody naukowe potwierdzają wprawdzie, że szczury mogą być nosicielami niebezpiecznych chorób. Wiadomo także, że mieszkają na nich pchły, będące nosicielami wielu patogenów, m.in. pałeczek dżumy i hantawirusów. Są zatem narażone na epidemię, która po zdziesiątkowaniu szczurzych populacji może zostać przeniesiona na inne gatunki, w tym ludzi. Istnieją więc przekonujące dowody na to, że obecność szczurów w ludzkich społecznościach może mieć istotny wpływ na rozprzestrzenianie się epidemii (Battersby 2015, 82). Nie ma jednak jednoznacznych danych wskazujących na poziom prawdopodobieństwa, że takie zagrożenie może wystapić. Wiadomo jedynie o czynnikach ryzyka zwiększających takie prawdopodobieństwo, wśród których wymienia się m.in. znaczący rozrost ośrodków miejskich w ostatnich dekadach oraz antropogeniczne zmiany klimatu wspierające rozwój szczurzych populacji. Sprawę komplikuje fakt, że nawet jeśli prawdopodobieństwo wystapienia epidemii jest bardzo niewielkie, nie wyklucza to innych zagrożeń sanitarnych, na przykład bolesnych pogryzień czy skażenia żywności. Aksjologiczne uwarunkowania procesów decyzyjnych oraz dyskurs warunkujący mentalne, instytucjonalne i legislacyjne ramy tego, co definiujemy jako problematyczne i wymagające podjęcia działań, wydają się więc zasadniczym czynnikiem zakłócającym możliwość „obiektywnej” oceny ryzyka.

Z podobnych powodów trudna do zastosowania może się okazać teoria praw. Jej główny orędownik Tom Regan nie porusza nigdzie problemu relacji między człowiekiem a wolno żyjącymi szczurami. Przyjmuje wprawdzie tak zwaną zasadę minimalizacji uchylenia 
praw i zasadę gorszego położenia (Gzyra 2015, 105), nie precyzuje jednak, kiedy zasadne jest ich użycie. Można jedynie domniemywać, że chodzi o sytuacje bezpośredniego zagrożenia życia, co, jak spróbowaliśmy dowieść wyżej, w przypadku relacji szczur-człowiek jest problematyczne. Bardziej użyteczna dla naszych rozważań może być koncepcja Sue Donaldson i Willa Kymlicki zawarta w ksiazzce Zoopolis. Political Theory of Animal Rights, w której autorzy analizują kwestię moralnego umocowania naszych relacji ze zwierzętami „liminalnymi”, a więc funkcjonującymi na pograniczu ludzkich społeczności i stanu dzikiego. Ich koncepcja zasadniczo bazuje na teorii praw zwierząt, ale w przeciwieństwie do koncepcji większości autorów tego nurtu sprzeciwia się pomysłowi „gatunkowego apartheidu” jako jedynej możliwej formie ochrony nie-ludzkich zwierząt przed ludzką opresją określając ów pomysł jako nierealistyczny. Proponują w zamian koncepcję miejskiego obywatelstwa (denizenship) (Donaldson i Kymlicka 2011, 14) opartego na międzygatunkowej koegzystencji, w której zwierzęta synantropijne zyskują podmiotowość i sprawczość - nie sa już tylko pacjentami moralnymi, ale także aktywnymi aktorami kształtującymi międzygatunkowe relacje, zdolnymi do aktów oporu. Taka optyka może trafnie określać miejsce wolno żyjącego szczura w ludzkiej społeczności. Jego wysoka adaptatywność, ostrożność w podejściu do przynęt i rozwijanie odporności na kolejne metody eksterminacji sprawiają, że wyłamuje się on $z$ narracji opisującej zwierzęta jako bierne ofiary ludzkiej opresji, dominującej w tradycyjnych teoriach praw zwierząt, stając się anarchistyczną figurą oporu. Donaldson i Kymlicka wyraźnie podkreślają przy tym, że w międzygatunkowej wspólnocie konflikty są nieuniknione. Zaznaczaja, że sprawiedliwość nie musi oznaczać przyjaźni (Donaldson i Kymlicka 2011, 244), konieczne jest za to przemyślenie, co to znaczy dzielić społeczeństwo i ryzyko z innymi gatunkami. Jako zwolennicy teorii praw zwierząt wyraźnie sprzeciwiają się jednak metodom letalnym w kontroli populacji szczurów. Za jedyną moralnie dopuszczalną metodę uznaja prewencję, jeśli ta zaś nie skutkuje, proponuja korzystanie z żywołapek, a następnie wypuszczanie szczurów w innym miejscu, w którym nie sprawiaja problemów (Donaldson i Kymlicka 2011, 246).

O ile sama koncepcja zoopolis wydaje się ważnym i potrzebnym punktem odniesienia dla budowania strategii międzygatunkowej kohabitacji, to przedstawiona w książce (dodajmy, że dosyć wybiórczo) propozycja radzenia sobie z problemami na linii szczur-człowiek zdaje się naiwna, co wynika z jej silnego zakorzenienia w deontologiczej teorii praw i z pomijania usytuowanego charakteru praktyk deratyzacyjnych, wykraczających poza optykę indywidualistyczną ${ }^{10}$. W podobną narrację wpisuja się rozważania Eriki Fudge, dotyczące etycznych wyzwań związanych z relacjami między człowiekiem a „szkodnikiem”. Autorka opisuje, jak w jej domu zamieszkal nieproszony gość - mysz, z którą z czasem udało

${ }^{10} \mathrm{O}$ deratyzacji jako formie praktyk usytuowanych zob. Beumer 2014. 
jej się wytworzyć relację opartą na dystansie i jasnym funkcjonowaniu granic, pozbawioną jednak przemocy (Fudge 2011). Możemy sobie wyobrazić, że zamiast myszy do mieszkania autorki mógłby zawitać szczur. Jeśli byłby to tylko jeden osobnik, zapewne jego relacja z gospodynią nie uległaby zmianie, podobnie jak ostrożnie optymistyczne wnioski płynące z eseju. Problem leży jednak w tym, że nasze relacje z dzikimi szczurami rzadko zasadzają się na spotkaniu indywidualnych podmiotów - ludzkiego i nie-ludzkiego. Ich sednem jest kontekst mnogości po obu stronach międzygatunkowej granicy: miasta liczące kilkaset tysięcy, a czasem kilka milionów przedstawicieli naszego gatunku współzamieszkuja wielotysięczne (a czasem wielomilionowe) populacje szczurów. Jesteśmy dwiema ogromnymi populacjami będącymi dla siebie wzajemnie poważnym zagrożeniem. Kwestia skali stawia nasze relacje w zupełnie innym świetle. Nawet jeśli uznajemy - a takie jest założenie stojące za niniejszym artykułem - że dbanie o indywidualny dobrostan i ochrona przed cierpieniem doznających jednostek są ważne, działania takie wymagaja zastosowania nowych narzędzi, które uwzględniałyby kontekst zbiorowości. Warto przywołać w tym miejscu koncepcję zwierzęcości jako mnogości Gilles’a Deleuze'a i Féliksa Guattariego, rozwijaną w Tysiac plateau (Deleuze i Guattari 2015, 281) ${ }^{11}$. W kontekście relacji między szczurem a człowiekiem owa mnogość nie jest wyłącznie metafora, ale staje się ważnym, materialnym kontekstem warunkującym nasze stosunki. Większość teoretyków związanych z optyką indywidualistyczną zdaje się nie zauważać tego problemu, wychodząc być może z założenia, że moralna troska o dobrostan osobniczy musi pociagać za sobą konieczność wyabstrahowania od kontekstu kolektywu.

III

Czym zatem dysponujemy, chcąc stworzyć zarys posthumanistycznego ludzko-szczurzego kolektywu? Przede wszystkim konieczne wydaje się przezwyciężenie dychotomii permanentnej wojny i harmonijnej koegzystencji poprzez przyjęcie agonistycznej optyki zaproponowanej przez Chantal Mouffe, zgodnie z którą konflikt jest elementem nieodzownie wpisanym w mechanizm funkcjonowania kolektywu, a nie zagrożeniem dla niego (Mouffe 2015). Taka perspektywa powinna zakładać jednoczesne uchylenie dwóch paradygmatów: antropocentrycznego z jednej i restrykcyjnie rozumianych praw zwierząt $z$ drugiej strony. Warunkiem brzegowym jest przy tym wyraźne uznanie szczurów za jednostki posiadające status moralny i uzupełnienie doktryny utylitarystycznej „granicą" deontologiczna, co oznaczałoby, że pewne szczególnie bolesne praktyki powinny być zakazane niezależnie

11 Więcej o symbolicznym statusie szczura w kontekście teorii zwierzęcości z Tysiaca plateau i jego konsekwencjach etycznych w artykule: G. Jarzębowska, Kanat jako to, co wyparte. Szczur wobec binarnej logiki nowoczesności (w przygotowaniu do druku). 
od ich efektywności. W ramach takiej doktryny można by uznać za dopuszczalne praktyki kontroli populacji szczurów, także te letalne, uzasadniając to dobrem ludzko-nieludzkiego kolektywu, pod warunkiem wszakże, że stanowiłyby one rozwiązanie ostateczne, realizowane po udowodnieniu nieskuteczności innych metod oraz tego, że nie powodują nadmiernego cierpienia zwierząt. „Nadmierne cierpienie” nie jest oczywiście pojęciem jednoznacznym i powinno być analizowane w odniesieniu do konkretnego kontekstu ekologicznego i społecznego. Można jednak wstępnie założyć, że wycofane z użycia powinny zostać te metody, które w kilku niezależnych badaniach wykazały wysoki negatywny wpływ na dobrostan, a więc m.in. antykoagulanty i pułapki lepowe.

Taka propozycja może wydawać się trudna do zrealizowania, biorąc pod uwagę, że wymienione metody stanowią ponad 90\% wszystkich środków stosowanych w eksterminacji szczurów. Warto jednak zaznaczyć, że sceptycyzm wobec masowo stosowanych antykoagulantów narasta także w środowiskach niemających wiele wspólnego z obrońcami zwierząt, głównie w obszarze IPM (integrated pest management) i EBRM (ecologicallybased rodent management), a więc wśród nurtów postulujących ograniczanie stosowania rodentycydów przede wszystkim z uwagi na powodowane przez nie zagrożenia ekologiczne oraz krótkofalowość efektów osiaganych za ich pomoca (np. Chambers i in. 1999, 216-217; Cowan $i$ in. 2003, 433; Meerburg i in. 2008). Podobnie jak w innych dyskusjach dotyczacych zakrojonych na szeroką skalę zmian systemowych (takich jak chociażby modyfikacja założeń systemu kapitalistycznego lub odejście od paliw kopalnych) także w dyskusjach wokół rodentycydów dominuje jednak narracja braku alternatywy, wzmacniana instytucjonalnie przez regulacje unijne, utrudniające rejestrację środków innych niż antykoagulanty ${ }^{12}$. Owo przekonanie o braku alternatywy wobec antykoagulantów jest efektem splotu wielu czynników, z których co najmniej część ma konkretne podłoże aksjologiczno-polityczne. Uzależnienie od antykoagulantów wydaje się ściśle związane z brakiem zainteresowania osób decyzyjnych wspieraniem skoordynowanych działań i badań nad ekologią miejskiego szczura. Dlaczego tak się dzieje? Wspomnieliśmy już o dominującej w strategiach nekropolitycznych narracji wojennej stanowiącej filtr interpretacyjny, przy pomocy którego określone treści ulegaja wzmocnieniu, inne zaś - stłumieniu lub wykluczeniu z debaty. W obszarze opracowywania praktycznych strategii w grę moga wchodzić jeszcze dwa czynniki. Pierwszy z nich, najbardziej oczywisty, może wiązać się $z$ aspektem finansowym. W optyce krótkoterminowej programy oparte na truciu są bowiem bardziej ekonomicznym

12 Chociaż w unijnej Dyrektywie o produktach biobójczych podkreśla się konieczność zmniejszenia negatywnego wpływu na dobrostan zwierząt, nie jest on jednak definiowany, co sprawia, że przepis jest de facto martwy. Także udowodniony naukowo negatywny wpływ antykoagulantów na dobrostan został przez autorów Dyrektywy pominięty. Jedyną obecną w niej wytyczną dotyczącą dobrostanu zwierząt, która może być wiążąca, jest zalecenie niedublowania eksperymentów na zwierzętach w procesie testowania produktów biobójczych, por. Smit 1999. 
rozwiązaniem niż inwestowanie w innowacyjne badania nad ekologia szczura i metodami alternatywnymi (np. antykoncepcja ${ }^{13}$ ), zwłaszcza jeśli ich przedmiotem jest zwierzę w powszechnym odbiorze tak mało charyzmatyczne. Ten wymiar problemu wydaje się mocno zakorzeniony w mechanizmach demokracji w stylu zachodnim. Można podejrzewać, że osoby sprawujące władzę mogą odczuwać opór przed inwestowaniem dużych środków publicznych, z których są rozliczane, w rozwiązanie problemu, który w społecznym odbiorze nie jest uważany za priorytetowy. Ponadto model zachodniej demokracji z założenia premiuje działania krótkoterminowe. Przekonanie osób decyzyjnych o wartości rozwiązania, które wedle wszelkiego prawdopodobieństwa okaże się korzystne w perspektywie 10-20 lat, stanowi trudne zadanie w sytuacji, gdy decyzje polityczne sa podejmowanie w cztero- lub pięcioletnim cyklu sprawowania władzy.

Czynnik drugi, na który warto zwrócić uwagę, łączy się z pojęciami tabu i wstydu, które wydają się w znacznym stopniu organizować politykę eksterminacji szczurów. Jeśli obecność tych zwierząt zostaje dostrzeżona w danej jednostce administracyjnej, podejmowane są natychmiastowe działania mające na celu pozbycie się problemu, rzadko natomiast podejmuje się szerszą dyskusję na temat przyczyn jego występowania i możliwych alternatyw dla masowego zabijania szczurów, nie wspominając o wspieraniu badań terenowych, które mogłyby niepotrzebnie przyciagnać uwage do wstydliwego problemu i niekorzystnie wpłynąć na reputację miasta lub dzielnicy (Parsons i in. 2017). Symboliczne utożsamienie szczurów z brudem i patologią sprawia zatem, że walkę z nimi prowadzi się w ukryciu. Jeśli te zwierzęta pojawiaja się w środkach masowego przekazu, to niemal wyłącznie w atmosferze sensacji, a nie w ramach wyważonej analizy. Nietrudno też zauważyć, że taka atmosfera nie sprzyja budowaniu empatii wobec zwierząt. Konieczna jest zatem zmiana społecznego postrzegania szczura. Robert Corrigan zwraca uwage na nieliczne pozytywne aspekty obecności tego gatunku, na przykład na fakt, że żywi się on karaluchami oraz przeprowadza „recykling” miejskich resztek zostawianych przez człowieka, stając się tym samym elementem miejskiego metabolizmu (Corrigan, 36). Oczywiście te aspekty nie powinny nam przesłonić negatywnego bilansu naszej kohabitacji i wiążących się z nia zagrożeń dla człowieka. Wydaje się jednak, że rozpoznanie różnych aspektów naszych wzajemnych relacji pomogłoby w przedstawieniu jej w całej swojej złożoności.

13 Testowane w ostatnich latach programy antykoncepcji dla szczurów (m.in. immunoantykoncepcja, ContraPest) wydają się wartą uwagi alternatywą dla metod letalnych. Nawet jeśli założymy, że mają one pewien wpływ na dobrostan, nie może on się równać z oddziaływaniem metod letalnych, które, jak zauważyliśmy, powodują często długa i bolesną śmierć. Stosowanie metod kontroli płodności przesunęłoby nasze działania z prostej eksterminacji na biopolitykę, która z filozoficznego punktu widzenia może być postrzegana jako dyskusyjna. Przyjmujemy jednak w tym miejscu, że biopolityka może być rozumiana jako odpowiedzialność za populacje zwierząt, które z uwagi na swój sposób życia są uznawane za problematyczne dla człowieka, a zarazem jako bodaj jedyna możliwa obecnie alternatywa dla zadawania śmierci na masową skalę. 
Dla wyjścia z nekropolitycznego paradygmatu, który zarysowaliśmy powyżej, i dla zbudowania międzygatunkowego kolektywu w praktyce kluczowe wydają się trzy kwestie. Pierwsza $z$ nich dotyczy zaangażowania w problem prozwierzęcych aktywistów, którzy zazwyczaj stanowią ważną grupę nacisku przy blokowaniu szczególnie okrutnych praktyk. Bez ich zainteresowania i aktywnej pracy (na przykład zainicjowania kampanii przeciwko stosowaniu pułapek lepowych) jakakolwiek zmiana jest mało prawdopodobna. Druga kwestia jest konieczność transparentności działań oraz włączenia do dyskusji mieszkańców, naukowców, dziennikarzy, komisji dialogu obywatelskiego i jednostek administracji publicznej. Transfer wiedzy pomiędzy różnymi aktorami zaangażowanymi w debatę wydaje się nieodzowny dla poprawy sytuacji. Stabuizowanie praktyk nie sprzyja bowiem ani wypracowywaniu efektywnych metod, ani dobrostanowi zwierząt. Zarazem należy jednak pamiętać, że sam transfer wiedzy może okazać się niewystarczający. Jeśli ksenofobia, rasizm, homofobia, transfobia, strach przed emigrantami i uchodźcami odzywaja się mimo szeroko zakrojonej debaty i pracy edukacyjnej, negatywny odzew tym bardziej może mieć miejsce w przypadku zwierząt budzących tak silny afekt u większości przedstawicieli naszego gatunku. Dlatego można zaryzykować tezę, że trzecim kluczowym elementem umożliwiającym zmianę społecznego postrzegania tego zwierzęcia - a tym samym, pośrednio, praktyk jego eksterminacji - powinna być praca na zbiorowej podświadomości. Mogłoby się to łączyć z upowszechnianiem alternatywnych kodów kulturowych określających wizerunek szczura, a tym samym jego status symboliczny. Ten wymiar pracy nad zmiana jest najtrudniejszy, jak każda forma przepracowywania zbiorowych lęków i traum wydaje się jednak konieczny do stworzenia alternatywnego modelu międzygatunkowej kohabitacji.

\section{Wnioski}

W powyższym tekście rozważyliśmy możliwość stworzenia teorii międzygatunkowej kohabitacji w mieście na przykładzie jednej z najbardziej problematycznych relacji między ludźmi a innymi zwierzętami, jaką jest relacja między człowiekiem i wolno żyjącym szczurem. Podkreśliliśmy, że kohabitacja nie musi oznaczać harmonijnej koegzystencji i że kontrola populacji szczurów jest niezbędna do funkcjonowania międzygatunkowego kolektywu, zaznaczając zarazem, że obecnie stosowane środki eksterminacji tych zwierząt powoduja ich długotrwałe cierpienie i powinny być zastępowane metodami mającymi mniejszy negatywny wpływ na dobrostan. Niniejszy tekst powinien być traktowany jako wstęp do pozbawionej przesądów dyskusji na temat zmian w politykach zarządzania populacjami nie-ludzkich zwierząt. Konieczne jest przy tym przełamanie spekulacji i ugruntowanie dyskursu dotyczącego międzygatunkowych relacji poprzez włączenie do niego praktycznej wiedzy o wielorakich aspektach ich kontroli. 


\section{Wykaz literatury}

Arnoldi, Jakob. 2011. Ryzy/ko. Tłum. Bartek Reszuta. Warszawa: Wydawnictwo Sic!

Bateson, Patrick. 1991. "Assessment of Pain in Animals.” Animal Behaviour 42, 827-839.

Battersby, Stephen. 2015. "Rodents as Carriers of Disease." W Rodent Pests and their Control.

Red. Alan Buckle, Robert Smith. Oxfordshire-Boston: CAB International.

Beatley, Timoty. 2011. Biophilic cities. Integrating nature into urban design and planning, Washington.

Beumer, Koen. 2014. "Catching the Rat: Understanding Multiple and Contradictory HumanRat Relations as Situated Practices.” Society \& Animals 22, 8-25.

Biehler, Dawn Day. 2013. Pests in the City: Files, Bedbugs, Cockroaches and Rats. Washington: University of Washington Press.

Broom, Donald. 1999. "The Welfare of Vertebrate Pests in Relation to Their Management." W Advances in Vertebrate Pest Management, vol. 1, Red. David Cowan, Chris Feare, Furth, Filander Verlag.

Chambers, Lisa, Malcolm Lawson i Lyn Hinds. 1999. "Biological Control of Rodents - the Case for Fertility Control Using Immunocontraception.” W Ecologically-based Management of Rodent Pests. Red. Grant Singleton, Lyn Hinds, Herwig Leirs, Zhibin Zhang. Canberra: Australian Centre for International Agricultural Research.

Corrigan, Robert. [b.d.]. "Chaper 1: Rats and Mice.” W Mallis Handbook of Pest Control. Cleveland: GIE Media.

Cowan, David P., Roger J. Quy i Mark S. Lambert. 2003. "Ecological Perspectives on the Management of Commensal Rodents." W Rats, Mice and People: Rodent Biology and Management. Red. Grant Singleton, Lyn Hinds, Charles Krebs, Dave Spratt. Canberra: Australian Centre for International Agricultural Research.

Cronon, William. 2013. [przedmowa]. W Dawn Day Biehler. Pests in the City, Files, Bedbugs, Cockroaches and Rats. Washington: University of Washington Press.

Davis, Hank. 1996. “Underestimating the Rat's Intelligence.” W Cognitive Brain Research 3 (34), 291-298.

Deleuze, Gilles i Félix Guattari. 2015. Tysiac Plateau. Kapitalizm i Schizofrenia II. Red. meryt. Joanna Bednarek. Warszawa: Fundacja Bęc Zmiana.

Diamond, Jared. 2010. Strzelby, zarazki, maszyny. Losy ludækich społeczeństw. Tłum. Marek Konarzewski. Warszawa: Prószyński Media.

Donaldson, Sue i Will Kymlicka. 2011. Zoopolis. A Political Theory for Animal Rights. New York: Oxford University Press.

Douglas, Mary. Red. 1982. Essays in the Sociology of Perception. London: Routledge, Kegan and Paul.

Feng, Alice i Chelsea G. Himsworth. 2014. "The Secret Life of the City Rat: a Review of the Ecology of Urban Norway and Black Rats (Rattus norvegicus and Rattus rattus)." Urban Ecosyst 17, 149-162.

Fudge, Erica. 2011. "Pest friends." W Uncertainty in the City. Red. Bryndis Snæbjörnsdóttir, Mark Wilson. Berlin: The Green Box. 
Graham, Elaine. 2002. Representations of the Post/ human. Monsters, Aliens and Others in Popular Culture. Manchester: Manchester University Press.

Groeneveld, Sarah. 2014. Animal Endings: Species Necropolitics in Contemporary Transnational Literature. Wisconsin-Madison: The University of Wisconsin-Madison.

Gzyra, Dariusz. 2015. „Teoria praw zwierząt Toma Regana a etyka środowiskowa”. W Filozofia wobec swiata zwierzat. Red. Dominika Dzwonkowska, Michał Latawiec, Dariusz Gzyra, Jacek Lejman, Mirosław Twardowski, Justyna Tymieniecka-Suchanek. Warszawa: Wydawnictwo Naukowe UKSW.

Hendrickson, Robert. 1983. More Cunning Than Men. A Social History of Rats and Men. New York: Kensington Press.

Herbrechter, Stefan. 2013. Posthumanism. A Critical Analysis. London: Bloomsbury.

Hwang, Joyce. 2013. "Living among pests. Designing the biosynthetic city." Volume Magazine $35,60-64$.

Jarzębowska, Gabriela. [w przygotowaniu do druku]. Kanat jako to, co wyparte. Szczur wobec binarnej logiki nowoczesności.

Jerolmack, Colin. 2014. "How Pigeons Became Rats. The Cultural Logic of Problem Animals." Soc Probl 55 (1), 72-94.

Kowalczyk, Agnieszka. 2010. „Wspólnota poszerzona. Spotkania ludzkich i nie-ludzkich aktorów”. Praktyka Teoretycźna 1, 116-135.

Larson, Brendon. 2013. "The Metaphorical Links Between Ecology, Ethics and Society." W Linking Ecology and Ethics for a Changing Worlds. Values, Philosophy and Action. Red. Ricardo Rozzi, S.T.A. Pickett, Clare Palmer, Juan J. Armesto, J. Baird Callicott. New YorkLondon: Springer.

Littin, Kate, Penny Fisher, Ngaio Beausoleil i Trudy Sharp. 2014. "Welfare Aspects of Vertebrate Pest Control and Culling: Ranking Control Techniques for Humaneness." Rev. sci. tech. Off. int. Epiz: 33 (1), 281-289.

Macdonald David, Fiona Mathews, Manuel Berdoy, “The behaviour and ecology of Rattus norvegicus: from oportunism to kamikaze tendencies" W Ecologically-based Management of Rodent Pests. Red. Grant Singleton, Lyn Hinds, Herwig Leirs, Zhibin Zhang. Canberra: Australian Centre for International Agricultural Research.

Makowska, Joanna i Daniel M. Weary. 2013. “Assessing the Emotions of Laboratory Rats." Applied Animal Behavious Science 148, 1-12.

Mason, Georgia i Kate Littin. 2003. “The Humaness of Rodent Pest Control.” Animal Welfare $12,1-37$.

Mbembe, Achille. 2003. "Necropolitics.” Public Culture 15 (1), 11-40.

Meerburg, Bastiaan, Frans Brom i Aize Kijlstra. 2008. "Perspective: Ethics of Rodent Control.” Pest Management Science 64 (12), 1205-1211.

Mouffe, Chantal. 2015. Agonistyka. Polityczne myślenie o świecie. Tłum. Barbara Szelewa. Warszawa: Wydawnictwo Krytyki Politycznej.

Nagy, Kelsi I Philip David Johnson II. Red. 2013. Trash Animals. How We Live With Nature's Filthy, Feral, Invasive and Unwanted Species. Minneapolis: University of Minnesota Press. 
Palmer Claire. 2003. "Placing Animals in Urban Environmental Ethics." Journal of Social Philosophy 34 (1), 64-78.

Parsons, Michael, P.B. Banks, M.A. Deutsch, Robert Corrigan I J. Munshi-South.2017. "Trends in Urban Rat Ecology: A Framework to Define the Prevailing Knowledge Gaps and Incentives for Academia, Pest Management Professionals (PMPs) and Public Health Agencies to Participate." Journal of Urban Ecology [w przygotowaniu].

Pearce, Fred. 2015. The New Wild. Why Invasive Species will be Nature's Salvation. Boston: Beacon Press.

Probucka, Dorota. 2013. Filozoficzne podstawy idei praw zpierzat. Kraków: Universitas.

Radomska, Marietta. 2010. “Towards a Posthuman Collective: Onthology, Epistemology and Ethics.” Praktyka Teoretyczna 1, 94-115.

Sabloff, Annabelle. 2001. Reordering the natural world. Humans and animals in the city. TorontoBuffalo-London

Sharp, Trudy i Glen Saunders. 2011. A Model for Assessing the Relative Humaneness of Pest Animal Control Methods. Canberra: Australian Government Department of Agriculture, Fisheries and Forestry.

Smit, Femmie. 2015. "Ethics in Rodent Control." W Rodent Pests and Their Control. Red. Alan Buckle, Robert Smith. Oxfordshire-Boston: CAB International.

Twine, Richard. 2010. Animals as Biotechnology. Ethics, Sustainability and Critical Animal Studies. London-Washington: Earthscan.

Weisberg, Zipporah. 2014. “Trouble with Posthumanism: Bacteria Are People Too.” W Critical Animal Studies. Thinking the Unthinkable. Red. John Sorenson. Toronto: Canadian Scholars' Press.

Winston, Mark. 1997. Nature Wars. People vs Pests. Cambridge-London: Harvard University Press.

Wolch, Jennifer. 2010. "Zoopolis", W Metamorphoses of the Zoo. Animal Encounter After Noah, red. R. R. Acampora, Lexington Book, New York-Toronto-Plymouth.

Young, Stephen. 2006. “On the Status of Vermin.” Between the Species 13 (6), 1-27.

Zinsser, Hans. 1935. Rats, Lice and History. London: Back Bay Books.

Żylińska, Joanna. 2013. Bioetyka w epoce nowych mediow. Warszawa: Instytut Badań Literackich PAN. 
Gabriela Jarzębowska - doktorantka na Wydziale Artes Liberales Uniwersytetu Warszawskiego. Założycielka i prezeska działającej w latach 2013-2017 fundacji Bios Amigos zajmującej się upowszechnianiem bezprzemocowych relacji człowieka ze środowiskiem nieludzkim. Lodzianka.

\section{DANE ADRESOWE:}

Wydział Artes Liberales

Uniwersytetu Warszawskiego, ul. Nowy Świat 69, 00-046 Warszawa

EMAIL: gabriela.jarzebowska@gmail.com

CYTOWANIE: Jarzębowska, Gabriela. 2017. „Podążaj za szczurem. Od nekropolityki do teorii międzygatunkowej kohabitacji." Praktyka Teoretyczna 1(23): 305-323.

DOI: $10.14746 /$ prt.2017.1.11

AUTHOR: Gabriela Jarzębowska

TITLE: Follow the Rat. From Necropolitics to Interspecies Cohabitation

ABSTRACT: This paper develops the concept of a posthumanist, more-than-human collective by focusing on conflictual relationships between humans and sewer rats. I propose to look at the absence of empathy in urban rat control programs through the framework of a necropolitics of war and colonization. I seek to examine how an interspecies community may be organized to simultaneously protect human interests and meet the requirements of animals' well-being. I analyze the reasons why the idea of a reduction in animals' suffering does not exist in public discourses on rat eradication. I claim that to create an interspecies collective composed of populations in conflict it is necessary to consider ideas of animal liberation and reconstruct cultural codes concerning rats.

KEYWORDS: rat, posthumanism, animal rights, necropolitics, collective 